\title{
Ethical Challenges and Practical Risks of Fieldwork Research in Development or Emergency Contexts
} Introduction

\section{Sylvie Ayimpam and Jacky Bouju}

\section{OpenEdition}

\section{Journals}

\section{Electronic version}

URL: http://journals.openedition.org/anthropodev/296

DOI: 10.4000/anthropodev.296

ISSN: 2553-1719

Publisher

APAD - Association pour l'anthropologie du changement social et du développement

\section{Printed version}

Date of publication: 1 September 2014

Number of pages: $43-45$

ISBN: 9791093476018

ISSN: 2276-2019

\section{Electronic reference}

Sylvie Ayimpam and Jacky Bouju, «Ethical Challenges and Practical Risks of Fieldwork Research in Development or Emergency Contexts », Anthropologie \& développement [Online], 40-41 | 2014, Online since 01 September 2016, connection on 23 September 2020. URL : http://journals.openedition.org/ anthropodev/296 ; DOI : https://doi.org/10.4000/anthropodev.296

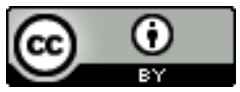

La revue Anthropologie \& développement est mise à disposition selon les termes de la Licence Creative Commons Attribution 4.0 International. 


\title{
Fieldwork in Development and Emergency Settings: Confluence and Renewed Reflexivity
}

\author{
Introduction : \\ Ethical Challenges and Practical Risks of Fieldwork \\ Research in Development or Emergency Contexts
}

Sylvie Ayimpam, Magali Chelpi-den Hamer, Jacky Bouju

The bygone figure of the lonesome ethnologist settled for a long time in an exotic distant village is fading away. New generations of social anthropologists stay out of office for much shorter fieldwork periods in order to investigate issues concerning close or distant places or people. They pay special attention to the diversity of local stakes and interests, to the multiplicity of opinions and understandings, to the complexity of other's world. They do worry about the intercultural encounter and the ethics of communication with research assistants and informers. All in all, social anthropologists are very reflexive about their field practice.

On their part, anthropologists of development have also contributed to the renewal of the discipline. They were the first to explore new ways of practicing ethnography in short term development programs. Anthropologists involved in emergency humanitarian relief programs took their path and relied heavily on ideas and concepts stemming from development anthropology (intervention capture and manipulation 'from the top' or 'from the bottom', the degree of embedding in the immediate project environment, actors' games and power strategies, etc.). But, last decades conflict and post-conflict situations tagged with collective atrocities and repeated violation of human rights have increased. Such a context has strongly impacted fieldwork exposing it to new difficulties, risks and hazards unknown before. Today, anthropology of emergency and development is fully involved in actual disciplinary stakes. New researches are centred on Aid organizations's internal logics and stakes arouse discussions and debates about the methodological innovations springing from emer- 
gency and development actions stand in good place amid these new researches. Some of them following the reflexive turn cogitate on personal involvement in aid programs. Yet, apart from the milestone book of Florence Bouillon, Marion Frésia and Virginie Tallio (2005), the French speaking anthropology of development and urgency kept uninvolved in this reflexive trend. Therefore, the aim of this issue is to start filling the gap. But, in doing so, we shall not follow the existing literature main stream which is mainly concerned with ethical and methodological problems stemming from doing fieldwork in very dangerous contexts or war situations (Nordstrom and Robben, 1995; Nilan, 2002; Sriram \& al., 2009). Indeed, all the papers gathered here deal with 'moderately' hazardous fieldworks.

Moderately hazardous fieldworks are interesting because they create a global atmosphere of faint insecurity. The researcher accepting to engage fieldwork in such context knows well that he (she) will find himself (or herself) caught in awkward and worrisome situations, some of them being more difficult to cope with than others. In this case, the right perception of risks is central and it depends of a fine and accurate understanding of what is at stakes for all parties interacting. In turn, this depends of the researcher's personal involvement in people's problems and how he has negotiated the various identities assigned to him. It also depends of the previous roles he has played locally and of the new roles he is ready to take upon himself.

In moderately risky situations, hazards stem from research topics that may be politically 'sensitive', socially 'illegitimate' or religiously 'taboo'. The specific difficulty of such topics is that they are characterized by conceptual clashes that make them 'elusive' and 'soaked' with antagonistic meanings that mistreat most of the basic methodology requirements (neutrality, cross control validation, etc.) This is made clear in Ramatou Ouedraogo and Hadiza Moussa's papers. They describe lengthily how they have been involved into tensed local antagonisms, concerning on one side abortion in an hostile and stigmatizing community context and on the other side, excision in a social context religiously explosive. Hazards may also originate in the authoritarian context surrounding fieldwork as shown in Molly Sundberg and Mikaela Le Meur's papers. In a situation filled with extreme political tension or religious hatred violence is likely to burst out at any moment. This has been Sylvain Batianga's experience in Central 
African Republic where he found himself caught in a local situation undermined by rampant suspicion against all 'humanitarian' fieldworkers.

Then, well informed about a risky fieldwork situation, knowing how much access to the research site may be hazardous, the researcher may cancel is leaving to the field. This is what happened to Sten Hagberg and Gabriella Körling. With the burst out of the Malian civil war, access to their research site became impossible. To cope with the situation, they engaged in a kind of 'distant survey', a methodological adaptive option that tends to be more and more used to circumvent field access difficulties. Today, extended fieldwork is threatened in several ways. On one side because of the generalization of insecurity problems that may cause hazards to the researcher, his assistants or his informers, and on the other side because of a continuous shrinking of institutional funding of anthropological field research. As a result, field research practice is becoming more and more complicated to implement. Therefore, many anthropologists explore ways and means adapting the classical participant observation method to these pressures. Sten Hagberg and Gabriella Körling's contribution gives a good idea of the many ways to take 'notes and queries' from afar that can be experimented nowadays.

Each paper in this issue illustrates a different way to question the ethical problems met when coping with risks on the field. They may be summed up in four main questions:

- How is fieldwork method knocked up and tinkered in authoritarian contexts where investigation is not welcomed and interviewing kept under surveillance?

- What particular ethical and methodological issues rise when fieldworking in sites becoming hazardous in pre or post-conflict situations?

- Is it possible to investigate any research topic whatever its sensibility?

- Finally, how much is direct fieldwork interaction necessary? What are the ethical and methodological limits of distant anthropological survey?

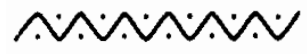

Sylvie Ayimpam is a social anthropologist at the Institute of African Worlds (IMAF), Aix-Marseille E-mail : ayimpam@mmsh.univ-aix.fr

Magali Chelpi-den Hamer is an anthropologist at the Institute of African Worlds (IMAF), Aix-Marseille 